\title{
GENETIC ANALYSIS OF SUPPRESSORS OF METHIONINE MUTANTS OF SALMONELLA TYPHIMURIUM
}

\author{
J. D. CHILDS \\ Microbiology Unit, Department of Biochemistry, University of Oxford \\ D. A. SMITH \\ Genetics Department, University of Birmingham
}

Received 8.xi.66

\section{INTRODUCTION}

Most suppressors appear to be specific for one or more mutants of a single gene, although this may be the result of limited testing. Suppressors of amber mutants are exceptions, as amber mutants are found in a number of genes with unrelated functions as in the bacteriophages $\mathrm{T}_{4}$ (Benzer and Champe, I962; Epstein et al., I963), $\lambda$ (Campbell, I96I) and $f_{2}$ (Zinder and Cooper, I964), and in the bacteria Escherichia coli (Garen and Siddiqi, I962) and Salmonella typhimurium (Whitfield, Martin and Ames, I 966). Suppressors of the yeast Saccharomyces cerevisiae isolated by Hawthorne and Mortimer ( 1963 ) may also be of this type (Manney, I964).

This paper describes the genetic specificities of suppressors of a methionine gene $(\operatorname{met} B)$ of Salmonella typhimurium LT2. Although they were probably not amber suppressors, some were able to suppress mutants from several genes whereas others were specific for one or more met $B$ mutations. The enzyme lacking in met $B$ mutants, cystathionine synthetase, converts $O$-succinylhomoserine and cysteine to cystathionine (Rowbury, I 964). It consists of four identical subunits each with a molecular weight of 40,000 (Kaplan, M. M., and Flavin, M., personal communication). The interallelic complementation map of the met $B$ gene is complex (Smith and Childs, I966) and thus a comparison of the pattern of suppressor specificity with the complementation map was attempted.

\section{MATERIALS AND METHODS}

Almost all the bacteria were mutants of strain LT-2 of Salmonella typhimurium, although a few were mutants of strain LT- 7 , mostly from the collection of Dr M. Demerec. All the methionine mutants are listed by Smith and Childs (1966). Quantitative measurements of growth rates were carried out as described by Morris and Woods (1959).

In transduction experiments overnight broth cultures were infected with donor bacteriophage $\mathrm{P}_{22}$ at a multiplicity of about 10 . Where possible a spot transduction method was used in which about $2 \times 10^{8}$ or $2 \times 10^{9}$ bacteria were spread on a plate and up to 9 drops of different donor phage preparations $\left(\mathrm{I} \times \mathrm{Io}^{10}\right.$ particles per $\mathrm{ml}$.) placed on separate areas of the plate (for details see Smith and Childs, I966).

The culture and storage of the bacteria, the preparation of phage lysates and the media and supplements used were as described by Smith (I96r) and Smith and Childs (I 966$)$. Minimal agar (MA) was enriched by the addition of $\mathrm{I} \cdot 25$ per cent. or 2.5 per cent. $\mathrm{v} / \mathrm{v}$ nutrient broth (EMA and ${ }_{2} \mathrm{EMA}$ respectively). 


\section{EXPERIMENTS AND RESULTS}

Isolation of suppressed metB mutants

The suppressed mutants used were detected as apparent reversions of metB mutants, which grew more slowly than wild type on MA. A growth rate similar to that of wild type was obtained if methionine or homocysteine was added to this medium. They were isolated from the 42 met $B$ mutants numbered between 23 and 335 which had no requirements other than methionine (Smith and Childs, I966-table I). Broth was inoculated with 50-200 cells of these met $B$ mutants and after overnight incubation, $\mathrm{O} \cdot \mathrm{I} \mathrm{ml}$. samples of these cultures (about $2 \times 1 \mathrm{I}^{9}$ orgs./ml.) and ten-fold concentrations of them were spread on MA in duplicate. After 3-6 days incubation colonies of different sizes were visible. The small colonies were picked, streaked on MA and reincubated. Approximately Io per cent. of these subcultured colonies grew slowly and the remainder grew as fast as wild type.

Thirty slowly growing strains were isolated by this method, but some were unstable. During a period of 18 months, 14 lost the ability to grow slowly on MA. On testing they were found to be either pure cultures of metB mutants or a mixture comprising metB mutants and less than $0^{\circ}$ I per cent. of slowly growing mutants, presumably because of reversion of the suppressor mutations. Such instability of suppressor mutations is not unusual (Yura, 1956; Dawson and Smith-Keary, I963; Brody and Yanofsky, I965), but the remaining I6 mutants were comparatively stable and were retained for genetic analysis. The mutant designation used indicates the order of isolation and the metB mutant from which the isolation was made, e.g. metB203-6 was the sixth slowly growing strain to be isolated from met $B$ mutants and it was isolated from metB203. If a strain was found to carry a suppressor the symbol $s u$ was inserted, e.g. metB203-su6.

\section{Genetic analysis of the slowly growing strains}

One genetic method to demonstrate the presence of a suppressor is to show that the mutant which is able to grow slowly on MA still carries the original auxotrophic mutation (Glanville, I960). This method could be used for the analysis of metB suppressors as the metB gene could be co-transduced with another methionine gene $(m e t F)$ at a frequency of about 30 per cent., and mutants of these two genes have different phenotypes; mutants of the met $B$ gene respond to homocysteine thiolactone whereas metF mutants respond to methionine only (Smith, I96I). Thus recombinants of the genotype metB metF+ can be selected from the cross $m e t F \times m e t B$.

The slowly growing strains were used as donors with metF 310 as recipient. Transduction mixtures were plated on MA+homocysteine and after incubation replicated to $\mathrm{MA}$ and $\mathrm{MA}+$ homocysteine. Colonies able to grow on MA+homocysteine but not MA were the result of co-transduction of metB and $m e t F^{+}$. In such cases this confirmed the presence of a $m e t B$ mutation in the donor and hence, 
indirectly, the presence of a suppressor. In crosses with II of the 16 mutants the frequency of co-transduction was $28-44$ per cent. (table I) thus confirming the presence of suppressors in them. Close linkage of these suppressors to the respective met $B$ mutations seemed unlikely because it would have resulted in an apparently reduced frequency of

TABLE I

Confirmation of suppressors by genetic analysis

\begin{tabular}{|l|r|r|r|}
\hline Donors & $\begin{array}{c}\text { No. of } \\
\text { colonies replicated }\end{array}$ & $\begin{array}{c}\text { No. with } \\
\text { metB phenotype }\end{array}$ & $\begin{array}{c}\text { Per cent. } \\
\text { co-transduction }\end{array}$ \\
\hline metBr94-I & 1196 & 356 & 30 \\
metB203-6 & 849 & 271 & 32 \\
metB231-7 & 913 & 299 & 33 \\
metB320-9 & $* 700$ & 0 & 0 \\
metB78-10 & $* 500$ & 0 & 0 \\
metB220-12 & 80 & 24 & 30 \\
metB223-14 & 218 & 69 & 32 \\
metB311-16 & $* 500$ & 0 & 0 \\
metB324-19 & $* 600$ & 0 & 32 \\
metB214-20 & 441 & 140 & 0 \\
metB239-22 & 203 & 0 & 28 \\
metB301-24 & 319 & 90 & 42 \\
metB220-26 & 67 & 28 & 44 \\
metB92-27 & 85 & 37 & 35 \\
metB223-28 & 210 & 74 & 36 \\
metB220-32 & 400 & 144 & \\
\hline
\end{tabular}

* Estimated numbers only.

The slowly growing strains, derived from metB mutants, were used as donors with $m^{2} F_{3} I O$ as recipient and the transduction mixtures were plated on $\mathrm{MA}+$ homocysteine. After incubation the colonies were replicated to $\mathrm{MA}$ and $\mathrm{MA}+$ homocysteine. In crosses where recombinants with the metB phenotype were found, the donors carried a met $B$ mutation, which confirmed, indirectly, the presence of a suppressor mutation in these strains.

co-transduction of $m e t B$ and $m e t F^{+}$and this was not observed. In the cases of metB320-9, 78-IO, 31 I-I 6 and 239-22 no co-transduction with $m e t F^{+}$was observed. This was probably because the suppressors were either closely linked to the respective $m e t B$ mutations and were therefore co-transduced with them or that the slowly growing strains were partial reversions, i.e. a different alteration at the same site as the original met $B$ mutation. As it was extremely difficult to distinguish slowly growing colonies from wild type on a replica plate, 25 colonies from each of these crosses were picked and streaked on to MA. Of these approximately one third were able to grow slowly on MA and two thirds were wild type. This confirmed that the alterations were close to, or at the same site as the $m e t B$ mutations.

\section{Suppressor specificity}

(a) Within the metB gene. The spot transduction method was used with all 70 met $B$ mutants as recipients and all i i suppressed met $B$ mutants as donors. The met $B$ mutants from which they had been isolated were also used as control donors. It was found that small 
colonies resulting from the transduction of a suppressor could be detected most easily when plating on $2 \mathrm{EMA}$; on MA these colonies were smaller, more irregular and took longer to appear. On either medium they could easily be distinguished from minute colonies resulting from abortive transduction, which tended to be even smaller and more uniform. Plates were incubated for 7 days at $37^{\circ}$ and then for a further 7 days at room temperature. They were examined at intervals for the appearance of small colonies. As the crosses were effectively intragenic the number of wild type recombinants was low (o-Io per spot) and so it was normally easy to distinguish these from the larger numbers of small colonies (20-100) resulting from the transduction of a suppressor. These small colonies were streaked onto MA to confirm their suppressed mutant phenotype.

TABLE 2

Suppressor specificity within the metB gene

\begin{tabular}{|c|c|c|}
\hline Suppressor & met $B$ mutants suppressed & $\begin{array}{l}\text { Average number of } \\
\text { small colonies/spot }\end{array}$ \\
\hline $\begin{array}{c}\text { metBIg4-suI } \\
\text { metB2o3-su6 } \\
\text { metB23I-su7 } \\
\text { metB220-suI2, } 26,32 \\
\text { metB223-suI4, } 28 \\
\text { metB214-su2o } \\
\text { metB3oI-su24 } \\
\text { metB. } 92-\text { su27 }\end{array}$ & $\begin{array}{c}\text { * probably } 194(B) \text { only } \\
\text { * probably } 203(E) \text { only } \\
\text { * probably } 231(A) \text { only } \\
220(\mathcal{J}), 223(K), 395(F), 402(\mathcal{J}) \\
220(\mathcal{J}), 223(K), 395(F), 402(\mathcal{J}) \\
92(A), 214(A) \\
78(I), 30 I(D) \\
16(A), I 7(A), 9^{2}(A), 214(A)\end{array}$ & $\begin{array}{l}\cdots \\
\cdots \\
\cdots 100 \\
50-100 \\
15-20 \\
20-40 \\
20-40\end{array}$ \\
\hline
\end{tabular}

* See text.

The letters in brackets indicate the complementation group of each metB mutant (Smith and Childs, 1966). All 70 metB mutants were used as recipients with the I I suppressed $m e t B$ mutants as donors using the spot transduction method. Suppression of a met $B$ mutant was indicated by the appearance of small colonies which when subcultured grew slowly on MA.

Six of the metB mutants (metBr94, 203, 23I, 239, 345 and 408) were too leaky to permit the development of small colonies even when the recipient cultures had been centrifuged and resuspended in saline. Suppressors of three of these, metBrg4-suI, 203-su6 and 23I-su7 (table 2) appeared to suppress no other metB mutants, although this was impossible to confirm, as transduction of these suppressors was not demonstrable using the leaky mutants metBr94, 203 or $23 I$ as recipients. Five suppressors, metB220-sur2, 26 and 32 and 223-sur 4 and 28, all suppressed metB220, 223, 395 and 402 . The frequency of transduction of metB220-suI2, 26 and 32 was about Io times higher than that of metB223-sur4 and 28, which in turn, were transduced at a frequency about double that of the transduction of metB mutants to wild type. Both metB2I4-su2O and 92-su27 suppressed metBg2 and $2{ }_{4} 4$ and in addition metB92-su27 suppressed metBr6 and 17 . Small colonies produced by the transduction of metB2I4-su2O were smaller and more 
difficult to detect than those of metB92-su27. This may explain the

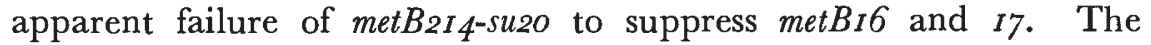
frequency of transduction of these suppressors and metB3oI-su24, which suppressed $m e t B 78$ and $30 I$, was low, probably no higher than met $B$ mutants.

The 70 met $B$ mutants can be divided into i 2 complementation groups A-L (Smith and Childs, 1966) represented as the map in fig. I. The $3^{\mathrm{I}}$ mutants of the largest group (A), fail to complement mutants of any other group. From a comparison with table 2 it can be seen that each of the six suppressors metB220-suI2, 26 and 32, 223-suI4 and 28 and $30 I$-su24, could suppress some but not all mutants from each

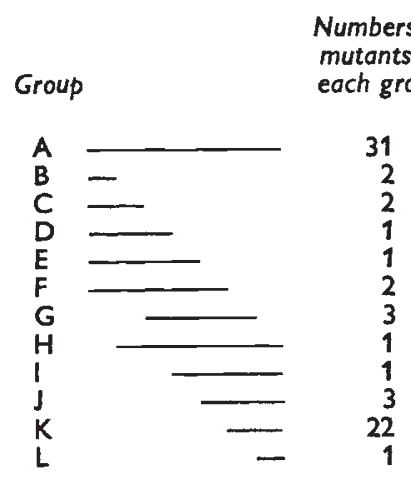

FIG. 1.-Complementation map of the metB gene (from Smith and Childs, 1966).

Overlapping lines in the map indicate failure to complement (after Catcheside, 1960).

of at least two complementation groups. For example, metB220-suI2 was able to suppress I of the 2 mutants of group F, 2 of the 3 mutants of group J and I of the 22 mutants of group K. None of the suppressors able to suppress mutants of the non-complementing group A (metB $23{ }^{I-}$ su7, 2I4-su2O and 92-su2) suppressed any mutants of the complementing groups B-L inclusive.

(b) Within other genes. Specificity experiments were extended to include $37 \mathrm{met} A, 16 \mathrm{met} C, 27 \mathrm{met} E, 21 \mathrm{met} F$ and $2 \mathrm{met} G$ mutants as recipients with all the suppressed $m e t B$ mutants as donors. Unlike the previous experiments donors and recipients carried mutant alleles of different genes, i.e. the crosses were intergenic, and the number of wild type recombinants was higher (20-50 per spot). As the size of these recombinant colonies varied greatly it was far more difficult to decide the phenotype of small colonies of the transduction plates. In many cases when small colonies were picked and streaked to MA these were found to be wild type recombinants.

Of the I03 methionine mutants tested, only two, metE2I7 and $E_{248}$ were suppressed and these by metB220-suI2, 26 and 32 and 223-suI 4 and 28. The pattern of suppression was the same as that of the metB mutants suppressed by these suppressors, i.e. a very high frequency of 
transduction of metB220-suI2, 26 and 32 and a lower frequency of transduction of metB223-suI4 and 28 (table 2).

It was decided to test a large number of auxotrophs resulting from mutations of a number of different non-methionine genes for suppression by these 5 suppressors to find out whether their action was restricted

TABLE 3

Suppressor specificity of metB22O-sul2, 26 and 32 and 223-sur 4 and 28

\begin{tabular}{|l|c|c|c|}
\hline \multicolumn{1}{|c|}{ Mutant } & No. tested & No. suppressed & Per cent. suppressed \\
\hline arginine & 82 & 5 & $6 \cdot \mathbf{I}$ \\
leucine & 124 & $1 \mathrm{I}$ & $8 \cdot 8$ \\
methionine & 166 & 6 & $3 \cdot 6$ \\
serine & 127 & 8 & $6 \cdot 3$ \\
thiamin & 20 & $\mathbf{I}$ & $5 \cdot 0$ \\
tryptophan & 165 & 6 & $3 \cdot 0$ \\
\hline Total & 684 & 37 & $\ldots$ \\
Overall mean per cent. suppressed & $\ldots$ & $\ldots$ & $5 \cdot 4$ \\
\hline
\end{tabular}

The auxotrophic mutants were tested for suppressor susceptibility with the 5 suppressors listed above as donors using the spot transduction method. The actual mutants suppressed are listed in table 4 .

to methionine genes only. As three of these suppressors (metB220-suI2, 26 and 32) were transduced at a frequency about Io times greater than the transduction of each recipient to wild type, it was easy to detect small colonies with the suppressed phenotype using the spot transduction method. In all, 518 mutants were tested for suppressor suscepti-

TABLE 4

Mutants suppressed by metB220-sui2, 26 and 32 and 223-sui 4 and 28

\begin{tabular}{|c|c|c|c|}
\hline $\begin{array}{l}\operatorname{argH} H_{97} \\
\operatorname{argIOI} \\
\operatorname{argAI50} \\
\operatorname{argH} H_{5 I} \\
\operatorname{argCI5} 8 \\
\text { leu }_{3} \\
\text { leu34 } \\
\text { leuI6I } \\
\text { leuI64 } \\
\text { leuI79 }\end{array}$ & $\begin{array}{c}\text { leur8o } \\
\text { leur95 } \\
\text { leu212 } \\
\text { leu216 } \\
\text { leu226 } \\
\text { leu258 } \\
\text { metB220 } \\
\text { metB223 } \\
\text { metB395 } \\
\text { metB402 }\end{array}$ & $\begin{array}{c}\text { metE217 } \\
\text { metE248 } \\
\text { serAr44 } \\
\text { serAI63 } \\
\text { serAr66 } \\
\text { serAr75 } \\
\text { ser205 } \\
\text { serA256 } \\
\text { serA } 284 \\
\text { serA285 }\end{array}$ & $\begin{array}{c}\text { thil } \\
\operatorname{try} C_{3} \\
\operatorname{try} D_{7} \\
\operatorname{try} B 6_{3} \\
\operatorname{try} A_{14} 8 \\
\operatorname{try} A 239 \\
\operatorname{try} B 24^{2}\end{array}$ \\
\hline
\end{tabular}

$\arg =$ arginine requirement.

$l e u=$ leucine requirement.

ser $=$ serine requirement.

$m e t=$ methionine requirement.

$t h i=$ thiamin requirement.

$t r y=$ tryptophan requirement.

bility. They required either arginine, leucine, serine, thiamin or tryptophan for growth and a small number of each type were suppressed. The proportions suppressed (including methionine mutants) varied from 3.6 per cent. of methionine and tryptophan mutants to 8.8 per cent. of leucine mutants with an overall average of 5.4 per cent. (table 3 ). The actual mutants suppressed are listed in table 4. 


\section{Growth rate of suppressed metB220 and metB223 mutants}

If the suppressors act by causing mistakes in protein synthesis, it is likely that the growth rates of suppressed mutants will be less than that of wild type even when supplied with an excess of the end product of the pathway, in this case methionine (Yanofsky, Helinski and Maling, I96r). The suppressed metB220 and metB223 mutants grew slower on MA than wild type but there appeared to be little difference on MA + methionine. This was confirmed when the growth rates of metB220, metB223, metB220-suI2, 26 and $32,223-$ suI $_{4}$ and 28 and wild type were measured in minimal medium supplemented with methionine. The generation time of all 8 strains was approximately 45 minutes. Thus these suppressors did not affect the growth rate of the suppressed met $B$ mutants when methionine was provided.

\section{DISCUSSION}

An interesting feature of the suppressors was that each had a characteristic transduction frequency (table 2). This was particularly noticeable for metB220-suI2, 26 and 32 which were transduced at a frequency about io times higher than metB223-suI 4 and 28 although all 5 suppressed the same mutants. Mutants of the same gene are normally transduced to wild type at a frequency characteristic for the gene, and for genes on different transducing fragments this frequency can vary up to roo fold (Ozeki, I959). Thus it is likely that metB22OsuI 2,26 and 32 are mutants of one gene and metB223-suI 4 and 28 mutants of another and that these genes are carried on different transducing fragments.

According to the theory of complementation of Crick and Orgel (1964) mutants of the same complementation group should be closely linked and have the same or a similar change in the tertiary structure of the protein. Therefore any suppressor which altered a particular change of tertiary structure might be expected to suppress all the mutants of one complementation group. For the metB suppressors this was not the case; 6 suppressors were able to suppress some, but not all, mutants from more than one complementation group and two suppressors were able to suppress two and four mutants respectively of the 3 I met $B$ mutants of group A (table 2). Therefore they probably act on particular codons rather than particular tertiary structure changes.

The suppressors appear to be of more than one type, i.e. those which were specific for met $B$ mutants and those which suppressed mutants from other genes as well, but the mechanism of suppression may be similar in each case. For example, in Escherichia coli the tryptophan suppressors isolated by Brody and Yanofsky (1963) may be specific for tryptophan mutants, whereas the amber suppressors (Benzer and Champe, I962; Garen and Siddiqi, I962) suppress amber mutants of many genes (Campbell, ig6 I; Epstein et al., I963; Zinder and Cooper, I 964 ) but both types probably act by misreading a mutant codon. 
The methionine suppressors may act by altering the intracellular environment, e.g. by a change in the $\mathrm{pH}$ or ionic content in such a way as to change the tertiary structure of a mutant protein so that it regains activity as suggested by Hawthorne and Mortimer (1963), although this is not supported by the comparison of the pattern of suppressor specificity with the met $B$ complementation map. Alternatively they may interfere with protein synthesis, although the mutants suppressed by metB220-sur2, 26 and 32 and 223-suI 4 and 28 are probably not " nonsense" mutants of the amber or ochre type, which cause chain termination (Brenner, Stretton and Kaplan, 1965) for two reasons. Firstly the met $B$ suppressible mutants are able to complement other met $B$ mutants and two of them, metB223 and metB395, complement each other. Secondly the suppressible tryptophan synthetase mutant ${ }_{t r y} C_{3}$ produces a tryptophan synthetase A protein capable of combining with normal $\mathrm{B}$ protein to form an enzyme able to catalyse the reaction indole $+\mathrm{L}$-serine $\rightarrow$ tryptophan (Ghilds, unpublished). It is unlikely that an A protein fragment produced as a result of a " nonsense" mutation could combine with B protein, particularly as the $\operatorname{try} C_{3}$ mutation occurs in a central region of the deletion map of the $\operatorname{try} C$ gene (Blume and Balbinder, 1966).

It is therefore likely that the suppressible mutants are missense mutants and the mechanism of suppression may be similar to the " mistake" hypothesis of Yanofsky, Helinski and Maling (r96r) and Brody and Yanofsky (1963). The suppressors would alter the translation of the missense codon causing the incorporation of a particular amino acid into a protein at a particular frequency in place of the amino acid coded for by the missense codon, thus producing enough enzyme to permit slow growth of the mutant on unsupplemented minimal agar. As the suppressed metB220 and metB223 mutants were able to grow as fast as wild type in minimal medium supplemented with methionine it is unlikely that the suppressors have a widespread effect on protein synthesis. Therefore although the suppressible missense codon must have appeared in the 5.4 per cent. auxotrophs tested, it is probably only used infrequently to code for an amino acid in Salmonella typhimurium. This is analogous to the amber codon UAG which is probably only rarely used for chain termination in $E$. coli and $\mathrm{T}_{4}$ phage (Brenner, Stretton and Kaplan, 1965).

\section{SUMMARY}

I. Thirty mutants able to grow slowly on minimal agar without methionine were isolated from metB mutants of Salmonella typhimurium. Of these 14 were unstable, 5 were probably partial reversions and II were suppressed.

2. Three of the suppressors were each specific for a different metB mutation, 5 were specific for the same four $\operatorname{met} B$ mutations and two and one were specific for two and four metB mutations respectively.

3. There was little, if any, correspondence between suppressibility 
and the complementation group of the suppressed metB mutants as some, but not all mutants from up to three complementation groups could be suppressed by the same suppressor.

4. The five suppressors specific for the same metB mutations appeared to be mutants of either of two genes each located on a different transducing fragment and were able to suppress $37(5.4$ per cent.) of 684 auxotrophs tested.

5. The mutants tested had requirements for either arginine, leucine, methionine, serine, thiamin or tryptophan, and one or more mutants of each type were suppressed. These mutants were probably missense rather than nonsense mutants, and the mechanism of suppression may involve an alteration in the translation of the missense codon.

Acknowledgments.-We are indebted to Miss Margaret Edwardson for excellent technical assistance and to the late $\mathrm{Dr} \mathrm{M}$. Demerec for supplying the majority of the auxotrophs used. One of us (J. D. C.) is also indebted to Dr Demerec for the opportunity of working in his laboratory at Brookhaven National Laboratory, Long Island, New York, for two months and to the Wellcome Trust for a travel grant for his purpose. J. D. C., who was supported by a D.S.I.R. Research Studentship and later by a Guinness Research Fellowship, included some of this work in a Ph.D. thesis submitted to the University of Birmingham in 1964 .

\section{REFERENCES}

BENZER, S., AND CHAMPE, S. P. I962. A change from nonsense to sense in the genetic code. Proc. natn. Acad. Sci. U.S.A., 48, I I I4-I I 2 I.

Blume, A. J., AND Balbinder, E. I966. The tryptophan operon of Salmonella typhimurium. Fine structure analysis by deletion mapping and abortive transduction. Genetics, N.Y., 53, 577-592.

BRENNER, s., STRETTON, A. o. W., AND KAPLAN, s. 1965. Genetic code: the " nonsense" triplets for chain termination and their suppression. Nature, Lond., 206, 994-998.

BRODY, s., AND YANOFSKY, c. I963. Suppressor gene alteration of protein primary structure. Proc. natn. Acad. Sci. U.S.A., 50, 9-16.

BRODY, s., AND YANOFSKY, C. I 965 . Mechanism studies of suppressor-gene action. 7. Bacteriol., go, 687-695.

CAMPBELl, A. I96I. Sensitive mutants of bacteriophage $\lambda$. Virology, 14, 22-32.

CATCHEside, D. G. Ig6o. Relation of genotype to enzyme content. Symp. Soc. gen. Microbiol., Io, 18 1-207.

CRICK, F. H. C., AND ORGEL, L. E. I 964 . The theory of inter-allelic complementation. 7. molec. Biol., 8, I6 I-165.

DAWson, G. W. P., AND SMITH-KEARY, P. F. 1963. Episomic control of mutation in Salmonella typhimurium. Heredity, Lond., 18, I-20.

EPSTEIN, R. H., BOLle, A., STEINBERG, C. M., KELLENBERGER, E., BOY DE LA TOUR, E., CHEVALlEY, R., EDGAR, R. S., SUSMAN, M., DENHARDT, G. H., AND LIELAUSIS, A. 1963. Physiological studies of conditional lethal mutants of bacteriophage $\mathrm{T}_{4} \mathrm{D}$. Cold Spring Harb. Symp. quant. Biol., 28, 375-394.

GAREN, A., AND SIDDIQI, O. I962. Suppression of mutations in the alkaline phosphatase structural cistron of E. coli. Proc. natn. Acad. Sci. U.S.A., 48, I I 2 I-I I 27.

glanville, E. 1960. Genetics of Salmonella typhimurium. Ph.D. Thesis, Trinity College, Dublin.

haWTHORNe, D. C., AND MORTimer, R. K. 1963. Super-suppressors in yeast. Genetics, N.Y., 48, 6 I 7-620.

MANNEY, T. R. I964. Action of a super-suppressor in yeast in relation to allelic mapping and complementation. Genetics, N.Y., 50, I09-1 2 I.

2 E 2 
MORRIS, J. G., AND WOODs, D. D. 1959. Inter-relationships of serine, glycine and vitamin $\mathrm{B}_{6}$ in the growth of mutants of Escherichia coli. 7. gen. Microbiol., 20, 576-596.

ozEKI, H. 1959. Chromosome fragments participating in transduction in Salmonella typhimurium. Genetics, N.r., 44, 457-470.

ROWBURY, R. J. 1964. Synthesis of cystathionine and its control in Salmonella typhimurium. Nature, Lond., 203, 977-978.

SMIrH, D. A. I96I. Some aspects of the genetics of methionineless mutants of Salmonella typhimurium. 7. gen. Microbiol., 24, 335-353.

smith, D. A., and childs, J. D. 1966. Methionine genes and enzymes of Salmonella typhimurium. Heredity, Lond., 2I, 265-286.

WHitfield, H. J., MARTiN, R. G., AND AMEs, B. N. I966. Classification of aminotransferase (C-gene) mutants in the histidine operon. F. molec. Biol. (in the press). YANOFSKY, C., HELINSKI, D. R., AND MALING, B. D. I961. The effects of mutation on the composition and properties of the A protein of Escherichia coli tryptophan synthetase. Cold Spring Harb. Symp. quant. Biol., 26, I I-24.

YURA, T. 1956. Suppressor mutations in purine-requiring mutants of Salmonella typhimurium. Genetic Studies with Bacteria. Publs. Carnegie Instn., 6I2, 77-86. ZINDER, N. D., AND COOPER, s. I964. Host-dependent mutants of the bacteriophage f2. I. Isolation and preliminary classification. Virology, 23, $152-158$. 